\title{
'LESS IS MORE': ZEN BUDDHIST PHILOSOPHICAL OUTLOOK TO SAVE OUR PLANET FROM HAZARDOUS TRASH AND MATERIALISTIC CONSUMERISM
}

\author{
Dr. Rupali Majumder
}

\begin{abstract}
Materialistic consumerism and hazardous trash have adverse affect on our environment. World is becoming a global market and big trash ground concurrently due to endless human wants spring from materialistic philosophy of life. This paper is a humble attempt to analyse and evaluate Zen Buddhist philosophy of 'less is more' as global ethics to save our planet from hazardous trash and materialistic consumerism.

There is more scope of observation, investigation and research on this topic.
\end{abstract}

Key words : Materialistic Consumerism, Minimalism, Zen Buddhism

Buddhism is essentially a practical and humanistic philosophy because of its earnest and perennial concern to a very practical question of human life, 'how can we remove suffering (Dukha) from life? All through his life, until getting Nirvāna Buddha sought answer to this question and after enlightenment his life mission was to spread his message to human race to teach the ways to remove suffering. After death of Buddha, Buddhism is divided into two sects- Theravāda (Hīnayāna) and Mahāyāna Buddhism. Zen Buddhism is a sect of Mahāyāna in Japan, which incorporates the ideas of Indian Mahāyāna Buddhist and Chinese Taoism. Zenism 
was originated at the time of most glistering Tang Dynasty (618907) of China and this sect was known as Ch'an school. Later on, Ch'an spread to Vietnam as Thien to korea as Seon and east to Japan (12 ${ }^{\text {th }}$ Century) as Zen Buddhism. Zen is Japanese translation of Chinese word 'Chan' that means 'Dhyāna' (Meditation). Hazardous trash and materialistic consumerism have adverse affect on our environment. This paper is a humble attempt to analyse and evaluate Zen Buddhist philosophy of 'less is more' as global ethics to save our planet from hazardous trash and materialistic consumerism. There is more scope of observation, investigation and research on this topic.

Buddhism is essentially a practical and humanistic philosophy because of its earnest and perennial concern to a very practical question of human life, 'How Essence of Buddhism: can we remove suffering (Dukha) from life?'All through his life, until getting Nirvāna Gautama Buddha sought answer to this question and after enlightenment his life mission was to spread his message to human race to teach the ways to remove suffering. He was silent about metaphysical investigation and two corner stone of original Buddhism 'Pratītya Samutpāda' (theory of dependent origination) and 'Anityavāda and Kșaṇikavāda' (theory of Impermanence and momentariness) are fundamental notion on which renunciation of human suffering is laid down.

\section{Emerge of Zen Buddhism :}

Buddhism was divided into two sects- Theravāda (Hīnayāna) and Mahāyāna Buddhism after death of Buddha. Zen Buddhism is a sect of Mahāyāna in Japan, which incorporates ideas of Indian Mahāyāna Buddhist and Chinese Taoism. Zenism was originated at the time of most glistering Tang dynasty (618-907) of China and this sect was known as Ch'anschool. Thecha'n branch of Mahāyāna Buddhism was introduced to china by Buddhist teacher Bodhidharma from India in sixth century. Later on it Cha'n spread to Vietnam as Thien, to Korea as Seon and east to Japan $\left(12^{\text {th }}\right.$ 
century) as Zen Buddhism. Zen is Japanese translation of Chinese word 'Chan' that means 'Dhyāna' (meditation)

Basic belief of Zen Buddhism: The essence of Zen Buddhist belief is that all human beings are inherently Buddha and every one of us is capable to discover our Buddha nature. Zen master Dozen (1200-53) emphasised on the Buddha nature found within mountains, rivers and all sentient and non-sentient beings. Search of truth is possible through intense meditation instead of logical or philosophical argument. Intuitive understanding is epistemological key on the path of enlightenment. Ultimate aim of Zen practice is to attain 'Satori' means enlightenment. The Japanese word ' $\mathrm{Mu}^{\prime}$ is often used in Zen writing which means 'no' or 'not', to express negation of ego or intellect in pursuit of 'Satori'. Argument, logic, intellectuality and language just wrap and apart the truth 'who are we?' from us.

There are some disagreement between original Buddhism and Zen Buddhism yet; both are agree on the point that desire for material world and thirst for objects are link to suffering.

Materialistic consumerism and hazardous trash : 'Materialism: a system that eats us from inside out' George Monbiot.

In modern world, materialism is associated with happiness, success and self-contentment. We are in illusion in pursuing of our happiness by buying and consuming products to meet our endless wants. We enslave ourselves to life style produced by global marketing. On line retailing is making this phenomena more faster and it's a blow upon sustainable consumption. Charles Kettering, research head of General Motor of America who introduced 'planned obsolescence' stated that rather than a satisfied one, a dissatisfied consumer is exactly what industry needed to create. Charles Kettering adopted a policy of the organised creation of dissatisfaction 'as observed by Professor Juliet B. Schor, as he knew industry to sell its goods required dissatisfied consumer. This is planned labyrinth of consumerism. Professor Amartya Sen and 
Martha Nussabaum, who have developed an account of 'human flourishing' and the 'capabilities' have opined that having too little can obviously prevent flourishing, but more alarming thing is that wanting too much might alienate us from family, friends and civil, political and cultural life. We are consuming recourses at alarming rate and it has a devastating effect on our planet two ways. Firstly, anthropocentric consumerist environmental philosophy pushes up to exploit nature and secondly trash disposal is becoming a global problem. River, ocean and seas all water bodies are becoming giant pit disposal tank affecting our environment. E-commerce packing waste is becoming a bigger issue. Materialistic consumerism and hazardous trash are integrally related. Mark Sagoff has rightly observed, "Consumption refers to the depletion of earth's resources and the exhaustion of its capacity to safely absorb emission and effluents. In this sense, consumption has to do with flow of materials and energy from earth through economy and back to earth and atmosphere as waste" ${ }^{\prime 1}$.

\section{Zen philosophical outlook - Less is more :}

To seek solution of this problem we can adopt philosophical attitude of Zen Buddhist ---'Less is more'. Zen Buddhist environmental philosophy is deeply rooted in love of nature. They pay fullest respect to nature and believe that nature deserve our love and respect as we love and respect our fellow being. D.T. Suzuki (1870-1966) who popularised Zen Buddhism in west, in the final chapter 'Love of Nature' of his classic book 'Zen and Japanese culture' very beautifully explain Zen Buddhist out look upon nature, that nature is not an object to conquer and turn wantonly to our service but a friend, as a fellow being who destined like ourselves for Buddha hood. He mentioned Zen wants to meet nature as friendly, well-meaning agent whose inner being is like our own. Further, he explained that nature is not our enemy standing always against us in a threatening attitude; it is not a power, which will crush us if we not crush it or bind it into our service. They emphasized a continuity and identity within the 
human order and nature. Christoper Read, a Carlifornia American Zen teacher has developed five 'eco-percept' in imitation of the traditional Buddhist precepts and two of them are very worthwhile to mention in this regard---

1. I vow to recycle everything. This includes glass, aluminium, tin, cardboard, plastic, paper and motor oil.

2. I vow to be an active and informed voter .Learn how your representatives have voted on environmental issue. Let them know when you do not agree with them and when you do.

Respect for authority, reverence for nature and kind consideration for other fellow being are inherited traits of Japanese people from generation to generation. They practise Zen Buddhist philosophy of 'Less is more' in all probable aspects of their life. Zen Buddhist follows the code that is 'position less position'. As influence of Zen Buddhism Japanese people who follow Zen Buddhism avoid unnecessary and superfluities of life. It has direct positive effect on environment. Less comfort, less consumption, less material enjoyment and avoiding unnecessary lavishness in life result on less exploitation of nature and in parallel way result on less hazardous trash upon mother earth. In modern terminology, it is 'minimalism'. Minimalism is a term originated in $20^{\text {th }}$ century and first coined as an American visual art specifically for abstract expressionism. Zen Japanese are minimalist in their simple way of life. They are far away from ruthless competition, conspicuous consumption, noise pollution, trap of consumerism and any kind of excess of urban contemporary life style. Principle of nonattachment to material things has profound influence on Zen minimalist life style of Japan. This minimalist outlook of Zen philosophy has influence on the development of Japanese culture, structural engineering and even in mental life they are minimalist as they are very judicious in use of emotions. Zen Buddhism is essentially a part of Japan's spiritual and aesthetic foundation. 
'Less is more' is an art of simple living, which can save us from trap of consumerism as a result nature, will not been exploited and hazardous trash will reduce.

\section{Conclusion :}

'Less is more' is not merely a philosophical or religious view. 'It is wisdom derived from Zen Buddhism with utmost relevance to present world. Our planet has been becoming both---a big market and pit ground at our doorstep. Our materialistic consumerism and endless wants are two major factors in fuelling this adverse environmental crisis. In a world of $21^{\text {st }}$ century, we attempt to nurture our love, respect, emotion and human relation with any form of matter or product. It is easy as global market is at our doorstep. We all know adverse effect of these activities. It is not possible to every one of us to be Zen Buddhist but we should adopt and popularise their outlook 'Less is more' as global ethics to save our planet from Hazardous trash and materialistic consumerism.

There is more scope of observation, investigation and research on this topic.

\section{Reference :}

1 Sagoff Mark, Consumption, Companion to Environmental Philosophy, page 473

\section{Bibliography :}

1. Desilva Padmasiri, Environmental Philosophy and Ethics in Buddhism, NewYork : St. Martin Press,1998.

2. Jamieson Dale, A Companion To Environmental Philosophy, Blackwell Publishing Ltd. 350 Main Street, Malden, MA 021485018, USA 2001.

3. Masuno Shunmyo, Zen The Art of Simple Living, Penguin Book publication, England 2018. 